\title{
SVEŠA MAKSĀŠANAS LĪDZEKḶA NELIKUMĪGAS IZMANTOŠANAS KVALIFIKĀCIJAS JAUTĀJUMI
}

\author{
ISSUES RELATING TO QUALIFICATION OF ILLEGAL \\ USE OF MEANS OF PAYMENT OF ANOTHER PERSON
}

\author{
Diāna Hamkova, Dr. iur.
}

Latvijas Universitātes Juridiskās fakultātes

Krimināltiesisko zinātṇu katedras docente

\section{Summary}

The analysis of the case law leads to the conclusion that today the predominating way of using means of payment of another person manifests itself as illegal use of internet banking by taking the so-called fast loans on behalf of another person. The qualification of such offences in the court practice is rather inconsistent: in comparable factual circumstances, these offences are qualified both as a real corollary of several independent criminal offences under the second paragraph of the Section 193 of the Criminal Law, as well as a separate continued criminal offence. Besides, the prevailing opinion in the case law holds that such an offence can only be qualified in accordance with the second paragraph of the Section 193 of the Criminal Law, and this position is rather debatable.

Atslēgvārdi: maksāšanas līdzeklis, internetbanka, ātro kredītu izkrāpšana, turpināts noziedzīgs nodarījums, noziedzīgu nodarījumu kopība

Keywords: means of payment, internet banking, defrauding of fast loans, continuous criminal offence, aggregation of criminal offences

\section{Ievads}

Likumdevējs atbildību par sveša maksāšanas līdzekḷa nelikumīgu izmantošanu ir noteicis Krimināllikuma ${ }^{1}$ (turpmāk arī KL) 193. panta otrajā daḷā. Aplūkojot tiesu praksi saistībā ar KL 193. panta otrās daḷas piemērošanu, jāteic, ka situācija kopš 2006. gada, kad tika veikts tiesu prakses apkopojums "Tiesu prakse par nelikumīgām darbībām ar finanšu instrumentiem un maksāšanas līdzekḷiem”, ${ }^{2}$ ir būtiski mainījusies. Laikā, kad tika veikts tiesu prakses apkopojums, galvenokārt izplatīta bija svešas maksājumu kartes nelikumīga izmantošana, kas izpaudās kā skaidras naudas noṇemšana bankomātā no

1 Krimināllikums: LV likums. Pieņemts 17.06.1998.

2 Tiesu prakse par nelikumīgām darbībām ar finanšu instrumentiem un maksāšanas līdzekḷiem, 2006. Pieejams: http://at.gov.lv/lv/info/summary/kriminaltiesibas/ [aplūkots 19.02.2020.]. 
maksājumu kartei piesaistītā konta, kā arī norēḳināšanās par pirkumiem vai pakalpojumiem. Šodien ir aktualizējies cits sveša maksāšanas lìdzekḷa nelikumīgas izmantošanas aspekts, proti, sveša maksāšanas līdzekḷa - internetbankas - nelikumīga izmantošana, ņemot tā saucamos àtros kredìtus citas personas vārdā. Šādu nodarījumu kvalifikācija tiesu praksē ir visai nevienveidīga. Ievērojot raksta ierobežoto apjomu, autores mērķis ir pievērsties diviem problēmjautājumiem saistībā ar ātro kredītu izkrāpšanu, izmantojot svešu maksāšanas līdzekli - internetbanku: 1) vai gadījumos, kad ātrie kredīti izkrāpti no dažādām kapitālsabiedrībām, izmantojot vienas personas maksāšanas līdzekli ar salīdzināmi nelielu starplaiku, nodarījums kvalificējams kā atseviškss turpināts noziedzīgs nodarījums vai arī kā vairāku noziedzīgu nodarījumu reālā kopība; 2) vai ātro kredītu izkrāpšana, izmantojot svešu maksāšanas līdzekli - internetbanku -, ņemot kredītus citas personas vārdā, kvalificējama tikai saskaṇā ar KL 193. panta otro dal̦u vai arī šāds nodarījums papildus kvalificējams saskaṇā ar KL 177. pantu vai 180. pantu.

\section{Ieskats tiesu praksē}

No tiesu nolēmumu apskata secināms, ka virknē gadījumu, kad persona, izmantojot citas personas lietošanā nodoto maksāšanas līdzekli - internetbanku -, pieprasījusi aizṇēmumus vairākās kreditěšanas kompānijās, nodarījums tiek kvalificēts kā vairāku patstāvīgu noziedzīgu nodarījumu reālā kopỉba saskaṇā ar KL 193. panta otro daḷu. Tā ar Rìgas pilsētas Latgales priekšpilsētas tiesas 2018. gada 17. janvāra spriedumu par vainīgu 28 noziegumu izdarī̌̌anā saskaṇā ar KL 193. panta otro dalu atzīta persona A, kura, nelikumīgi izmantojot svešu personas $C$ maksāšanas līdzekli, bija n,ēmusi personas $C$ vārdā kredìtus dažādos kreditēšanas uzṇēmumos laika posmā no 2017. gada 30. janvāra līdz 2017. gada 3. februārim. ${ }^{3}$ Lìdzīgs kvalifikācijas risinājums lasāms arī Gulbenes rajona tiesas 2016. gada 10 . novembra spriedumā. ${ }^{4}$

Pastāvot l̦oti līdzīgiem faktiskajiem apstākḷiem, ar Tukuma rajona tiesas 2016. gada 16. decembra spriedumu persona A atzìta par vainīgu KL 193. panta otrajā daḷā paredzētā noziedzīga nodarījuma izdarīšanā, kvalificējot to kā atsevišksu turpinātu noziedzīgu nodarījumu. No sprieduma teksta izriet, ka persona A no 2015. gada 27. oktobra līdz 2016. gada martam nelikumīgi izmantoja personas B lietošanā nodoto maksāšanas līdzekli, pieprasot aizṇēmumus dažādās kapitālsabiedrībās. ${ }^{5}$ Kà turpināts noziedzìgs nodarījums kvalificēts arī personas D nodarïjums, kura no 2015. gada jūlija līdz 2017. gada jūnijam, izmantojot personas F maksāšanas līdzekli - internetbanku -, ne mazāk kā 89 reizes noformēja ātros kredītus uz personas F vārda. ${ }^{6}$

Kā redzams, pastāvot salīdzināmiem faktiskajiem apstākḷiem, kvalifikācija ir kardināli atšķirīga. Tā kā šo lietu kategorijā pamatā ir saīsinātie spriedumi un kriminālprocesi, kuros noslēgta vienošanās par vainas atzišanu un sodu, - argumenti vienam vai otram kvalifikācijas risinājumam diemžēl izpaliek. Viens no

\footnotetext{
Rīgas pilsētas Latgales priekšpilsētas tiesas 17.01.2018. spriedums krimināllietā Nr. 11310010817.

4 Gulbenes rajona tiesas 10.11.2016. spriedums krimināllietā Nr. 11170004616.

5 Tukuma rajona tiesas 16.12.2016. spriedums krimināllietā Nr. 11390045616.

6 Daugavpils tiesas 21.02.2019. spriedums krimināllietā Nr. 11320011518.
} 
kritērijiem, kas, iespējams, ietekmē procesa virzìtāja izšķiršanos par labu vienam vai otram kvalifikācijas variantam, ir laika intervāls starp nodarījumiem.

\section{Atsevišķa turpināta noziedzīga nodarījuma izpratne}

Turpināta noziedzīga nodarījuma pazīmes ir normatīvi nostiprinātas KL 23. panta trešajā daḷā, likumdevējam nosakot, ka atsevišķu turpinātu noziedzīgu nodarījumu veido vairākas savstarpēji saistītas tādas pašas noziedzīgas darbības, kas vērstas uz kopēju mērksi, ja tās aptver vainīgās personas vienots nodoms, tāpēc savā kopumā tās veido vienu noziedzīgu nodarījumu.

Turpināta noziedzīga nodarījuma kritēriji savā laikā jau tika ietverti Latvijas Republikas Augstākās tiesas plēnuma 2001. gada 14. decembra lēmuma Nr. 3 "Likuma piemērošana krimināllietās par svešas mantas nolaupišanu" 7.5. punktā, kurā skaidrots, ka par turpinātu nolaupī̌sanu uzskatāma tāda svešas mantas vairākkārtēja nelikumīga paņemšana no viena un tā paša īpašnieka vai valdītāja valdījuma, kas sastāv no vairākām vienveidīgām noziedzīgām darbībām, kurām ir vienots nodoms un kopējs galamērksis - nolaupìt mantu noteiktā daudzumā vai apmērā - un kuras savā kopībā izveido vienotu noziedzīgu nodarījumu. Tāpat tiek norādīts, ka par turpinātu nevar uzskatìt mantas nolaupīšanu, ja tā izdarīta dažādās vietās, no dažādiem avotiem, ar atšķirīgu nolaupīšanas veidu vai atšḳirīgos apstākḷos vai ja sekojošā mantas nolaupī̌sana notikusi pēc ilgāka laika ar atsevišķi radušos nodomu, kaut arī nolaupišanas veids ir bijis viens un tas pats. ${ }^{7}$ Augstākās tiesas plēnuma lēmums nav zaudējis savu aktualitāti arī šodien, turklāt, izvērtējot to, vai nodarījums atbilst turpināta noziedzīga nodarījuma pazīmēm, uzskaitītie kritēriji tiek ņemti vērā ne vien mantas nolaupīšanas lietās, bet arī citu lietu kategorijās. Jautājumi, kas skar turpinātu noziedzīgu nodarìjumu, ir aplūkoti arī judikatūrā. ${ }^{8}$

Turpināta noziedzīga nodarījuma izpratne nostiprināta arī tiesu prakses apkopojumā "Tiesu prakse par nelikumīgām darbībām ar finanšu instrumentiem un maksāšanas līdzekḷiem”, kurā skaidrots, ka par turpināta maksāšanas lìdzekḷa nelikumīgu izmantošanu uzskatāma vairākkārtēja citai personai piederošu naudas lìdzekḷu izņemšana un/vai izlietošana, norēķinoties par pirkumiem vai pakalpojumiem, kas izdarīta ar nelielu starplaiku no viena un tā paša avota (konta) ar vienveidīgām darbībām, kurām ir vienots nodoms un kopējs galamērķis - iztukšot kontu vai iegūt maksimāli iespējamo summu, iegādāties preces līdz brīdim, kamēr darījumam kontā ir pietiekams segums. ${ }^{9}$

Māris Leja pamatoti akcentējis, ka, orientējoties vienīgi pēc tiesu nolēmumos vai apkopojumos norādītajām pazīmēm, faktiski notiek attālināšanās no likuma, aizmirstot tajā norādīto, ka turpinātu noziedzīgu nodarījumu veido 1) vairākas

7 Likuma piemērošana krimināllietās par svešas mantas nolaupī̌sanu: Latvijas Republikas Augstākās tiesas plēnuma 2001. gada 14. decembra lēmums Nr. 3, 7.5. punkts. Grām.: Latvijas Republikas Augstākās tiesas plēnuma lēmumu krājums. Rīga: Latvijas Policijas akadēmija, 2002, 76. lpp.

8 Sk., piemēram: Augstākās tiesas 14.04.2015. lēmums lietā Nr. SKK-0089-15; Augstākās tiesas 28.02.2013. lēmums lietā Nr. SKK-76/2013; Augstākās tiesas 13.09.2011. lēmums lietā Nr. SKKJ-509/2011; Augstākās tiesas 19.12.2011. lēmums lietā Nr. SKK-671/2011; Augstākās tiesas 17.04.2009. lēmums lietā Nr. 155-/2009.

9 Tiesu prakse par nelikumīgām darbībām ar finanšu instrumentiem un maksāšanas līdzekḷiem, 2006. 
savstarpēji saistītas tādas pašas noziedzīgas darbības, 2) kas vērstas uz kopēju mērḳi, ja 3) tās aptver vainīgās personas vienots nodoms. ${ }^{10}$

Tas, ka turpināta noziedzīga nodarījuma izpratne šodien ir problemātiska un atsevišķas turpināta noziedzīga nodarījuma pazīmes mūsdienu apstākḷos ir visai diskutablas, izriet no atsevišķu autoru atziṇām. ${ }^{11}$ Ievērojot raksta ierobežoto apjomu, autore ìpaši vēlas pakavēties pie laika intervāla kā vienas no pazīmēm, kam tiek pievērsta uzmanība turpināta noziedzīga nodarījuma gadījumā. Laika intervāls neapšaubāmi varētu būt nozīmīgs, lai atzītu, ka starp vairākām vienveidīgām darbībām pastāv savstarpēja saistība, tas varētu arī liecināt par personas subjektīvo ievirzi. Domājams, ka noziedzīga nodarījuma objektīvo pazìmju ìpatnības var būtiski ietekmēt to, vai noziedzīgs nodarījums atzīstams par turpinātu vai nav. Tā, piemēram, laika intervāls vienas kategorijas nodarījumos objektīvi var būt ar lielāku atstarpi nekā citos. ${ }^{12}$ Tiesību literatūrā pamatoti akcentēts, ka noziedzīga nodarījuma turpinātais raksturs nemainās no tā, vai starp vairākiem nodarījumiem pagājis nosacīti ilgāks laika posms. ${ }^{13}$ Arī Vācijas Federālā Augstākā tiesa ir atzinusi, ka konkrēts laika intervāls, kas būtu uzskatāms par pietiekamu, lai nodibinātu turpinātam noziedzīgam nodarījumam nepieciešamo saistību starp noziedzīgām darbībām, nav nosakāms visiem gadījumiem vienoti. Šeit ir nepieciešams visu nozīmīgo faktoru kopvērtējums. ${ }^{14}$

Profesors Uldis Krastiņš pamatoti norādījis, ka, izlemjot jautājumu par to, vai izdarìts turpināts noziedzīgs nodarījums vai arī vairāki tādi paši noziedzīgi nodarījumi veido nodarījumu reālo kopību, katrs gadījums jāvērtē individuāli, atbilstoši konkrētajiem reālajiem apstākḷiem. ${ }^{15}$ Šādu viedokli būtībā paudis arī Māris Leja, norādot, ka likumā doto turpināta noziedzīga nodarījuma definīciju nav iespējams precizēt ar iepriekš jau gatavu un detalizētu pazìmju sarakstu. ${ }^{16}$

Analizējot turpināta noziedzīga nodarījuma kritērijus, profesors Uldis Krastiņš akcentē vienotu nolūku kā vienu no galvenajiem saistelementiem turpinātā noziedzīgā nodarījumā. Par vienoto nolūku profesora ieskatā var liecināt sistemātiska prettiesisko darbību izdarīšana. Krimināltiesībās ar sistemātiskumu saprot personas izdarītas vismaz trīs tādas pašas prettiesiskas darbības. ${ }^{17}$

Ievērojot iepriekš teikto, gadījumos, kad persona vairākkārt izmanto vienas personas maksāšanas līdzekli ar nelielu laika intervālu un ātrie kredīti tiek ņemti dažādās kapitālsabiedrībās, nodarījums ir kvalificējams kā atsevišḳs

${ }^{10}$ Leja M. Krimināltiesību aktuālie jautājumi un to risinājumi Latvijā, Austrijā, Šveicē, Vācijā. Noziedzīga nodarījuma uzbūve; cēloṇsakarība; vaina; krimināltiesību normu interpretācija un spēks laikā. I daḷa. Rīga: Tiesu namu aǵentūra, 2019, 867.-868. lpp.

11 Sk.: Krastiņš U. Turpināta noziedzīga nodarījuma problemātika krimināltiesībās. Grām.: Tiesību zinātnes uzdevumi, nozīme un nākotne tiesību sistēmās. Latvijas Universitātes Juridiskās fakultātes 7. starptautiskās zinātniskās konferences rakstu krājums. Rīga: LU Akadēmiskais apgāds, 2019; Leja M. 2019, 861.-883. lpp.

12 Лихолая В., Хамкова Д. О понятии и признаках продолжаемого преступного деяния. Сборник XVI Международной научно практической конференции «Уголовное право: стратегия развития в XXI веке» 24-25 января 2019 года. Москва: МГЮА, с. 574.

13 Козлов А., Севастьянов А. Единичные и множественные преступления. СПб: Издательство Юридический центр-Пресс, 2011, с. 57.

14 Vācijas Federālās Augstākās tiesas lieta: Urteil vom 07.04.1993., Str. 517/92, 32. rdk; Vācijas Federālās Augstākās tiesas lieta: Beschluss vom 19.05.1993., Str.645/92, 15. rdk. Citēts pēc: Leja M. 2019, 861.-883. lpp.

15 Krastiņš U. 2019, 348. lpp.

16 Leja M. 2019, 868. lpp.

17 Krastiņš U. 2019, 350. lpp. 
turpināts noziedzīgs nodarījums. Ja laika intervāls ir lielāks starp sveša maksāšanas līdzekḷa izmantošanas reizēm, katrā gadījumā būtu individuāli izvērtējams, kādi tam ir cēloṇi, vai persona šādi ir rīkojusies drošības nolūkos u. tml.

\section{Internetbankas izmantošana ātro kredītu izkrāpšanā - Krimināllikuma 193. panta otrā daḷa vai arī kopība ar Krimināllikuma 177. vai 180. pantu}

Pievēršoties otram jautājumam, proti, vai ātro kredītu izkrāpšana, izmantojot svešu maksāšanas lìdzekli - internetbanku -, n,emot kredītus citas personas vārdā, kvalificējama tikai saskaṇā ar KL 193. panta otro daḷu un vai šāds nodarījums satur arī krāpšanas pazīmes, jānorāda, ka arī šis jautājums tiesu praksē tiek risināts nevienveidīgi, neraugoties uz to, ka Augstākā tiesa ir skaidri paudusi savu nostāju, norādot, ka "mantas nolaupišana un maksāšanas līdzekḷa nelikumīga izmantošana nav jākvalificē kā noziedzīgu nodarījumu ideālā kopība. Krimināllikuma 193. panta otrajā dậa norādītā maksāšanas līdzekḷa izmantošana uzskatāma par speciālo normu attiecībā pret normām, kurās paredzēta atbildība par mantas nolaupišanu". ${ }^{18}$ Pēc Augstākās tiesas lēmuma publicēšanas G̣enerālprokuratūra izsūtīja visām Latvijas prokuratūrām informatīva rakstura vēstuli, akcentējot, ka gadījumos, kad izmantots citas personas maksāšanas līdzeklis internetbanka -, lai noformētu un saņemtu aizdevumu citas personas vārdā, darbības ir jākvalificē tikai saskaṇā ar KL 193. panta otro daḷu. ${ }^{19}$ Tomēr, neraugoties uz Augstākās tiesas atziṇām un Latvijas Republikas G̣enerālprokuratūras norādēm, tiesu prakse šajā jautājumā vēl joprojām nav vienveidīga.

Tiesu prakses apkopojumā "Tiesu prakse par nelikumīgām darbībām ar finanšu instrumentiem un maksāšanas līdzekḷiem” tika norādīts, ka KL 193. panta otrās daḷas izpratnē maksāšanas līdzekḷa izmantošana ietver sevī jebkuru rīcību ar maksājumu kartei piesaistītajā kontā esošajiem naudas lìdzekḷiem un papildu kvalifikācija saskaṇā ar citiem Krimināllikuma pantiem nav nepieciešama. ${ }^{20} \breve{S}_{1}$ atziņa konsekventi tika nostiprināta arī vairākos Augstākās tiesas nolēmumos. ${ }^{21}$ Akcentējams, ka tieši uz šo tēzi atsaucas gan aizstāvība, gan tiesas, gan atseviškos gadījumos apsūdzības uzturētāji, lūdzot tiesu izslēgt krāpšanu no sākotnējās apsūdzības. ${ }^{22}$

Kā jau tika norādīts, neskatoties uz judikatūras atziṇām, tiesu praksē ir gadījumi, kad joprojām tiek veidota noziedzīgu nodarījumu kopība. ${ }^{23}$ Judikatūrā nostiprināto pozīciju ir apšaubījis arī G̦enerālprokuratūras krimināltiesiskā departamenta Tiesās izskatāmo krimināllietu nodaḷas virsprokurors

18 Augstākās tiesas 16.11.2015. lēmums lietā Nr. SKK-542/2015; Augstākās tiesas 08.08.2017. lēmums lietā Nr. SKK-J-405/2017.

${ }^{19}$ Latvijas Republikas G̦enerālprokuratūras 04.12.2015. informatīvā vēstule Nr. 1/1-11-145-15.

20 Tiesu prakse par nelikumīgām darbībām ar finanšu instrumentiem un maksāšanas līdzekliem, 2006.

21 Sk.: Augstākās tiesas 19.11.2016. lēmums lietā Nr. SKK-496/201; Augstākās tiesas 16.11.2015. lēmums lietā Nr. SKK-542/2015.

22 Sk., piemēram: Zemgales tiesas 14.03.2018. spriedums krimināllietā Nr. 11370048214. Pirmstiesas izmeklēšanā personai B apsūdzỉba celta gan saskaņā ar KL 193. panta otro daḷu, gan 177. panta pirmo daḷu. Zemgales tiesa, atsaucoties uz 2006. gada tiesu prakses apkopojumā un judikatūrā paustajām atzin̄ām, personu B viṇam celtajā apsūdzībā saskaṇā ar KL 177. panta pirmo daḷu attaisnoja.

23 Sk., piemēram: Rīgas pilsētas Vidzemes priekšpilsētas 09.03.2018. spriedums krimināllietā Nr. 11091053316; Rīgas rajona tiesas 04.01.2018. spriedums krimināllietā Nr. 11351012415. 
Alēns Mickevičs, paužot viedokli lietā Nr. SKK-197/2017,24 kā arī Rīgas apgabaltiesa, akcentējot, ka internetbanka kā maksāšanas lìdzeklis tiek izmantota ne tikai naudas operācijām, bet arī attālinātai personības apliecināšanai un aizdevuma līguma noslēgšanai ar kredìtdevējiem, vainīgajam uzdodoties par citu personu. ${ }^{25}$ Arī raksta autores ieskatā uzskats, ka personas nodarījums šādos gadījumos kvalificējams tikai saskaņā ar KL 193. panta otro dal̦u, ir visai diskutabls.

Sākotnēji būtu noskaidrojams jautājums, vai tēze - KL 193. panta otrās daḷas izpratnē maksāšanas lìdzekḷa izmantošana ietver sevī jebkuru rīcību ar maksājumu kartei piesaistītajā kontā esošajiem naudas lìdzekḷiem un papildu kvalifikācija saskaņā ar citiem Krimināllikuma pantiem nav nepieciešama - vispār ir attiecināma uz tiem gadījumiem, kad kā maksāšanas līdzeklis tiek izmantota internetbanka. No tēzes teksta skaidri izriet, ka šì atziṇa tiek attiecināta tikai uz vienu no maksāšanas līdzekḷa veidiem - maksājumu karti, savukārt internetbanka kā maksāšanas līdzeklis, ievērojot gan tās fiziskos parametrus, gan funkcionālās iespējas, kardināli atš̌kiras no maksājumu kartes.

Kredītiestāžu likuma 1. panta 38. punktā tiek skaidrots, ka maksāšanas līdzeklis ir līdzeklis (atsevišḳi vai kopā ar citu maksāšanas līdzekli) vai maksājuma instruments, kurš lauj tā lietotājiem saṇemt skaidru naudu vai citas lietas, saṇemt vai veikt maksājumus, dot rīkojumu naudas līdzekḷu pārvedumam vai apstiprināt naudas līdzekḷu pārvedumu un kuru kā maksāšanas līdzekli pieṇem arī tās personas, kas nav laidušas apgrozībā šo maksāšanas līdzekli. Par maksāšanas līdzekḷiem uzskata skaidru naudu, čekus, maksājumu kartes (kredītkartes, debetkartes un citas tamlīdzīgas kartes), bankomātu kartes, maksājuma dokumentus, elektronisko naudu, attālinātu elektronisko kredītiestāžu operāciju (globālajā datortīklā vai izmantojot datoru vai tālruni) programmatūru un citus tamlìdzīgus lïdzeklıs. ${ }^{26}$

No dotā definējuma secināms, ka internetbanka ir attālināta elektronisko kredītiestāžu operāciju (globālajā datortīklā vai izmantojot datoru vai tālruni) programmatūra. Internetbankas specifika atškirīibā no maksājumu kartes ir tā, ka internetbanka nav materializēts priekšmets, turklāt to funkcionāli var izmantot ne tikai maksājumu veikšanai, bet arī attālinātai personības identificēšanai. Pateicoties šim aspektam, internetbanka kā maksāšanas līdzeklis tiek izmantota kā personības identifikācijas līdzeklis, personai noslēdzot ar kapitālsabiedrību distances līgumu un uzdodoties par citu personu. Savukārt ātro kredìtu izsniegšanas kompānijas pārstāvis, būdams maldināts par tās personas identitāti, kura pieprasa kredītu, piešḳir aizdevumu attālināti.

Tādējādi internetbankai kā maksāšanas līdzeklim raksturīgas visai specifiskas pazīmes, kas tās lietotājam paver iespējas plašam darbību spektram. Tā rezultātā arī kvalifikācijas risinājumam vajadzētu būt atšķirīgam. Persona nelikumīgu internetbankas izmantošanu var izdarīt, pārskaitot tai piesaistītajā kontā esošos naudas līdzekḷus uz savu vai citas personas kontu dažādu maksājumu veikšanai u. tml. Šādā gadījumā, pēc autores domām, nodarījums kvalificējams tikai saskaṇā ar KL 193. panta otro daḷu, jo persona, izmantojot citas

\footnotetext{
24 Augstākās tiesas 31.05.2017. lēmums lietā Nr. SKK-197/2017.

25 Rīgas apgabaltiesas 05.10.2017. spriedums krimināllietā Nr. 11517093014.

${ }^{26}$ Kredītiestāžu likums: LV likums. Pieņemts 05.10.1995.
} 
personas maksāšanas līdzekli - internetbanku -, rīkojas ar internetbankai piesaistītajā kontā esošajiem naudas līdzekliiem. ${ }^{27}$

Kā izriet no tiesu prakses, svešs maksāšanas līdzeklis - internetbanka - galvenokārt tiek izmantots ātro kredītu izkrāpšanai. Un tā jau ir specifiska situācija, kas prasa arī atšķirīgu kvalifikācijas risinājumu. Ātro kredītu izkrāpšanas gadījumā, izmantojot svešu maksāšanas lìdzekli - internetbanku -, rīcība nenotiek ar kontā jau esošiem naudas līdzekḷiem, bet gan, slēdzot distances līgumu, persona izkrāpj no kredītkompānijas naudas līdzekḷus, kas tiek ieskaitīti personas kontā, pēc tam vainīgā persona šos naudas līdzekḷus pārskaita uz savu kontu vai citas personas kontu. Tādējādi tie ir nevis kontā jau esoši naudas līdzekḷi, bet gan naudas līdzekḷi, kas tiek iegūti krāpniecisko darbību rezultātā. Šāds faktisko apstākḷu kopums nosaka nepieciešamību nodarījumu kvalificēt saskaṇā ar KL 193. panta otro dal̦u un KL 177. vai 180. pantu.

Turklāt bez ievērības nevar atstāt faktu, uz kuru pamatoti vērš uzmanību Alēns Mickevičs: "Šādos gadỉjumos nav pamata konstatēt tiesību normu konkurenci, jo KL 193. pantā ir paredzēta atbildība par paša maksāšanas līdzekḷa nelikumīgu izmantošanu un tas neaptver krāpšanu, ar kuru tiek apdraudēts cits noziedzīga nodarījuma objekts, - ātro aizdevumu sabiedrību mantiskās intereses, savukārt maksāšanas līdzekḷa nelikumīga izmantošana, identificējoties dažādu ātro aizdevumu sabiedrību elektroniskajās sistēmās un noslēdzot distances līgumus cietušo vārdā, ir tikai veids, kādā izpaužas krāpšanas objektīvā puse." 28

Tāpat jānorāda, ka internetbanka kā personības identifikācijas līdzeklis tiek izmantota ne vien maksājumu veikšanai, bet arī autorizējoties tādās vietnēs kā www.latvija.lv, www.datamed.lv, www.manabalss.lv u. c.

No Rīgas pilsētas Vidzemes priekšpilsētas tiesas 2019. gada 12. februāra sprieduma ${ }^{29}$ izriet, ka laika posmā no 2011. gada 29. septembra līdz 2012. gada 28. maijam persona $A$, droši zinot, ka viņa vecāmāte, persona $B$, ir mirusi, vairākkārt pieslēdzās personas B norēķinu konta internetbankai un veica pārskaitijumus gan uz saviem kontiem, gan personas B kontiem, gan arī citu personu kontiem. Tādā veidā persona A nelikumīgi izmantoja personas B maksāšanas līdzekli. Turklāt persona A nelikumīgi izmantoja svešu maksāšanas līdzekli: 2012. gada 23. decembrī ap plkst. 16.23 persona A nolūkā attālināti parakstīties par iniciatīvu "Noteikt pazemināto PVN likmi pārtikai" interneta vietnē $w w w . m a n a b a l s s . l v$ pieslēdzās personas B norēķinu konta internetbankai un personas B vārdā veica balsojumu par iniciatīvu "Noteikt pazemināto PVN likmi pārtikai" interneta vietnē www.manabalss.lv. 2013. gada 5. janvārī nolūkā attālināti parakstīties par iniciatīvu "Samazināt PVN likmi apkurei" interneta vietnē $w w w$.manabalss.lv pieslēdzās personas B norēķinu konta internetbankai un personas B vārdā veica balsojumu par iniciatìvu "Samazināt PVN likmi apkurei" interneta vietnē www.manabalss.lv. 2013. gada 14. maijā ap plkst. 19.57 persona A nolūkā attālināti parakstīties par iniciatīvu "Rīgas īstā uzvaras laukuma atjaunošana" interneta vietnē www.manabalss.lv pieslēdzās personas B norēḳinu konta internetbankai un personas B vārdā veica

\footnotetext{
27 Tīri teorētiski nav izslēgts, ka persona, izmantojot svešu maksāšanas līdzekli - internetbanku -, pārskaita tai piesaistītajā kontā esošos naudas līdzekḷus, piemēram, terorisma finansēšanai; pastāvot šādiem apstākḷiem, būtu izvērtējams, vai nodarījums nesatur arī terorisma finansēšanas pazīmes.

28 Augstākās tiesas 31.05.2017. lēmums lietā Nr. SKK-197/2017.

${ }^{29}$ Rīgas pilsētas Vidzemes priekšpilsētas tiesas 12.02.2019. spriedums krimināllietā Nr. 11092060814.
} 
balsojumu par iniciatìvu "Rìgas īstā uzvaras laukuma atjaunošana" interneta vietnē $w w w$. manabalss.lv.

Kā redzams, svešs maksāšanas līdzeklis - internetbanka - šajā kriminālprocesā izmantots, personai autorizējoties interneta vietnē www.manabalss.lv, lai veiktu balsojumu citas personas vārdā. Lai arī konkrētajā gadījumā maksāšanas līdzeklis - internetbanka - faktiski pilda personības identifikācijas funkciju, nevis savu pamatfunkciju - maksājumu veikšanu -, formāli šāds nodarījums satur KL 193. panta otrās daḷas pazīmes.

\section{Kopsavilkums}

1. Tiesu prakses analīze l̦auj secināt, ka šodien aktualizējusies tāda sveša maksāšanas līdzekḷa kā internetbanka izmantošana, ņemot tā saucamos àtros kredītus citas personas vārdā. Šādi nodarījumi tiesu praksē tiek kvalificēti divējādi: gan kā vairāku patstāvīgu noziedzīgu nodarījumu reālā kopība saskaņā ar KL 193. panta otro daļu, gan kā atseviškss turpināts noziedzīgs nodarijums, atzīstot personu par vainīgu viena noziedzìga nodarījuma izdarī̌šnā.

2. Gadijjumos, kad persona vairākkārt nelikumīgi izmanto vienas personas maksāšanas līdzekli - internetbanku -, turklāt tas notiek ar nelielu starplaiku, nodarījums būtu kvalificējams kā atseviškss turpināts noziedzīgs nodarījums. Tas, vai laika intervāls starp atsevišķām maksāšanas līdzekḷa izmantošanas reizēm ir neliels, katrā gadījumā būtu izvērtējams individuāli.

3. Izvērtējot, vai vairāki nodarījumi veido atsevišķu turpinātu noziedzīgu nodarījumu, tiesību normas piemērotājam primāri būtu jāievēro KL 23. panta trešajā daḷā nostiprinātās turpināta noziedzīga nodarījuma pamatpazìmes.

4. Judikatūrā nostiprinājies uzskats, ka personas nodarījums gadījumos, kad tiek izmantots svešs maksāšanas lìdzeklis - internetbanka -, ṇemot ātros kredītus citas personas vārdā, kvalificējams tikai saskaṇā ar KL 193. panta otro daļu, ir visai diskutabls.

4.1. N̦emot vērā, ka šādos gadījumos internetbanka kā maksāšanas līdzeklis tiek izmantota ne tikai naudas operācijām, bet arī attālinātai personības identifikācijai un distances līguma noslēgšanai ar kredītdevējiem, vainīgajam uzdodoties par citu personu, šāds nodarijums satur gan 193. panta otrās daḷas pazīmes, gan arī krāpšanas pazīmes, tāpēc tas būtu kvalificējams kā noziedzīgu nodarījumu ideālā kopība.

5. Situācijās, kad persona, izmantojot citas personas maksāšanas līdzekli internetbanku -, rīkojas ar internetbankai piesaistītajā kontā esošajiem naudas līdzekḷiem, kvalifikācija būtu veicama saskaṇā ar KL 193. panta otro dalı.

6. Kā rāda tiesu prakse, citas personas maksāšanas līdzeklis - internetbanka var tikt izmantots, personai autorizējoties dažādās interneta vietnēs, lai, piemēram, veiktu balsojumu, un formāli šāds nodarījums arī satur KL 193. panta otrās daḷas pazìmes. 